\title{
The investigation of factors determining wind power prediction accuracy: case study of western Lithuania
}

\author{
Giedrius Gecevičius ${ }^{1}$, \\ Mantas Marčiukaitis², \\ Marijona Tamašauskien $\dot{e}^{2}$ \\ ${ }^{1}$ Kauno Kolegija, \\ University of Applied Sciences, \\ Pramones Ave. 22, \\ 50468, Kaunas, Lithuania \\ Email:Giedrius.Gecevicius@go.kauko.lt \\ ${ }^{2}$ Lithuanian Energy Institute, \\ Breslaujos St. 3, \\ 44403, Kaunas, Lithuania
}

\begin{abstract}
In order to mitigate climate change, more attention every year is being given to wind energy. However, despite minimal impact of wind turbines on the environment, there is a negative side as well. Wind speed variations are a stochastic process, and it is difficult to predict wind power accurately. Therefore, unpredictable power can disbalance the power grid; besides, huge power reserves are necessary. Wind energy can be forecasted based on statistical, physical or hybrid methods and models. However, all methods and models generate power prediction errors during different time horizons. The paper presents an analysis of wind power prediction errors determining factors based on statistical, physical and hybrid approaches. Investigation revealed that combination of statistical methods - nonlinear regression, model output statistics, the most suitable power curve and wind speed correction methods - reduced wind power prediction errors up to $1.5 \%$. A detailed evaluation of relief variations and surface roughness increased wind power accuracy by $2 \%$. Considering the local conditions of the western part of Lithuania, the best suitable tool for a short-term wind power prediction is a hybrid model including a detailed description of topographical conditions and the most precise statistical methods.
\end{abstract}

Keywords: wind power forecasting, hybrid model, physical approach, statistical methods

\section{INTRODUCTION}

Wind energy is one of the most rapidly growing energy sectors around the world. In the end of 2016, the global installed capacity of wind power reached $487 \mathrm{GW}$ and annual addition was $55 \mathrm{GW}$ [1]. To compare, during the last decade in Lithuania, the installed power of wind turbines increased from a few megawatts to $518 \mathrm{MW}$ in 2017. However, it is not the end, because of very ambitious targets of the energy sector in Lithuania. In the National Energy Independence Strategy of the Republic of Lithuania it is defined that renewable energy sources for electricity (RESe) generation should make up to $45 \%$ by 2030 , and $100 \%$ by 2050 [2]. The main RESe should be wind energy with increased power capacity of 2.5 times by 2030 .

However, wind energy is not a stable power generation source, and in order to ensure secure 
and reliable power system function, it is important to predict power as accurately as possible. There are many different methods to do that, but there are still relatively large power prediction errors in different time horizons. For a shortterm (1-6 h) wind power forecasting, the best suitable are statistical methods not including assessment of meteorological and topographical conditions [3-4]. On the contrary, for midterm and long-term wind power forecasting physical methods are more accurate. Unfortunately, there are no sufficiently accurate tools to predict wind energy for all-time horizons. Due to this reason, it is necessary to design new methods which include statistical and physical approaches and estimate the influence of as many factors as possible [5].

The paper continues the authors' earlier research [6-7] and presents analysis of topographical variations and roughness length, reveals local wind conditions in the western part of Lithuania, and includes statistical methods for a more accurate wind power prediction process.

\section{METHODOLOGY}

For the evaluation of local topographical conditions, 2 wind farms with different parameters were chosen. Wind farms were located in the western part of Lithuania, near the coastline of the Baltic Sea. Annual wind speed was $3.02 \mathrm{~m} / \mathrm{s}$ (Klaipeda) at $10 \mathrm{~m}$ height in 2016 (Klaipeda meteorological station's data). The installed power capacity of analysed wind farms varied in the range of 14-16 MW with a number of turbines (6-7). The installed power capacity of wind turbines was 2-2.75 MW and hub heights reached 78 and $100 \mathrm{~m}$ (Table 1 ).

In order to evaluate surface variations, the Wind Atlas Analysis and Application Programme (WAsP 9) was used with the resolution of $5^{\star} 5 \mathrm{~km}$ squares and to describe surface rough- ness length and relief variation in four squares. Roughness length was estimated by the following equation [8]:

$$
z_{0}=0.5 \frac{h S}{A_{h}}
$$

where $h$ is the height of obstacle (m), $S$ is the area of obstacle $\left(\mathrm{m}^{2}\right)$, and $A_{h}$ is the total area of the site under assessment $\left(\mathrm{m}^{2}\right)[8]$.

Wind speed and direction data from the HIRLAM model was taken at $100 \mathrm{~m}$ height. Selected data and measurements are in 1-hour intervals and cover the period of 01.09.201531.12.2015 (4 months). For the evaluation of wind speed variation on different height, the following equation is used [9]:

$$
u_{V E}=u_{\text {HIRLAM }} \frac{\ln \frac{z_{V E}}{z_{0}}}{\ln \frac{z_{\text {HIRLAM }}}{z_{0}}},
$$

where $u_{\text {HIRLAM }}$ is the predicted wind speed $(\mathrm{m} / \mathrm{s})$, $z_{V E}$ is the hub height of wind turbine $(\mathrm{m}), z_{\text {HIRLAM }}$ is the height where wind speed is predicted $(\mathrm{m})$, $z_{0}$ is roughness length.

Statistical method's ARIMA function is presented as follows [10]:

$$
y_{t}=\boldsymbol{\alpha}+\boldsymbol{\phi}_{1} y_{t-1}+\ldots+\boldsymbol{\phi}_{p} y_{t-p}+\ldots+\boldsymbol{\theta}_{1} \boldsymbol{\varepsilon}_{t-1}+\ldots+\boldsymbol{\theta}_{q} \boldsymbol{\varepsilon}_{t-q}+\boldsymbol{\varepsilon}_{p}
$$

where $\alpha$ is constant term, $\phi_{i}$ is $i$-th autoregressive parameter, $\theta_{j}$ is $j$-th moving average parameter, $\varepsilon_{t}$ is error term at the time $t, y_{t}$ is hte value of wind power $(\mathrm{m} / \mathrm{s}, \mathrm{kW})$ at time $t(h)$. The adoption period of ARIMA function was 48 hours.

In order to minimize wind power prediction errors, including seasonality factor, an additional SARIMA equation was used [11]:

$$
\text { SARIMA }=\text { ARIMA }(p, d, q) \cdot(P, D, Q) s,
$$

Table 1. Parameters of the analysed wind farms

\begin{tabular}{c|c|c|c|c|c|c}
\hline Title of wind farm & $\begin{array}{c}\text { Installed } \\
\text { power of wind } \\
\text { farm (MW) }\end{array}$ & $\begin{array}{c}\text { Number } \\
\text { of wind } \\
\text { turbines }\end{array}$ & $\begin{array}{c}\text { Model of wind } \\
\text { turbine }\end{array}$ & $\begin{array}{c}\text { Installed } \\
\text { power of wind } \\
\text { turbine (MW) }\end{array}$ & $\begin{array}{c}\text { Hub height of } \\
\text { wind turbine (m) }\end{array}$ & Wind farm location \\
\hline Laukžemè WF & 16 & 6 & Vestas V100 & 2.75 & 100 & Western Lithuania \\
\hline Sūdènai WF & 14 & 7 & Enercon E82 & 2 & 78 & Western Lithuania \\
\hline
\end{tabular}


where $p, d, q$ are estimated autoregressive and moving average parameters (seasonality is not included), $P, D, Q$ are estimated autoregressive and moving average parameters (seasonality is included), $s$ is the number of time steps for a single seasonal period.

The model output statistics (MOS) method for the correction of predicted power is described according to the following equation [12]:

$$
P_{M O S}=a P+b,
$$

where $P$ is predicted power $(\mathrm{kW}), a$ and $b$ are statistical parameters.

In order to evaluate wind power prediction error, the normalized mean absolute percentage error (nMAPE) by the following formula was used [13]:

$$
\text { nMAPE }=\frac{1}{n} \sum_{i=1}^{n} \frac{\left|p_{i}(P)-\hat{p}_{i}(P)\right|}{p(N P)} \cdot 100 \%,
$$

where $p_{i}(P)$ is actual wind power $(\mathrm{kW}), \hat{p}_{i}(P)$ is predicted power $(\mathrm{kW}), p_{i}(N P)$ is maximum actual wind turbine power $(\mathrm{kW})$.

\section{RESULTS}

\section{Assessment of topographical conditions}

Investigation of roughness length coefficients acceptance in Sūdènai and Laukžemè wind farms was made. A comparison of wind power prediction errors considering combined roughness length (all wind directions) and roughness length estimated by different wind directions is presented in Fig. 1. It was noticed that in case of usage of different by wind directions roughness length indicators, nMAPE was insignificantly lower. Only in North and West directions in the Laukžemè wind farm, power forecasting results were better when a combined surface roughness indicator was used. However, average evaluation allowed us to identify that better power prediction results were achieved when a different roughness length for each direction sector was chosen. Differences of power prediction errors were just up to $0.1 \%$.

In the sites of the investigated wind farms, poorer trees and forests were identified. Due to this reason, to evaluate the impact of that on power prediction accuracy, different forests roughness length coefficients were chosen: typical - 0.4, lower than typical -0.2 , and higher than typical - 0.5. Analysis of power prediction, with different forest roughness length coefficients of the Südenai wind farm is presented in Fig. 2.

The lowest power prediction errors were determined in East and South directions, when 0.2 coefficient was used. To compare, the best results were in North direction with the surface roughness length coefficients 0.2 and 0.4 . West direction results were significantly better with

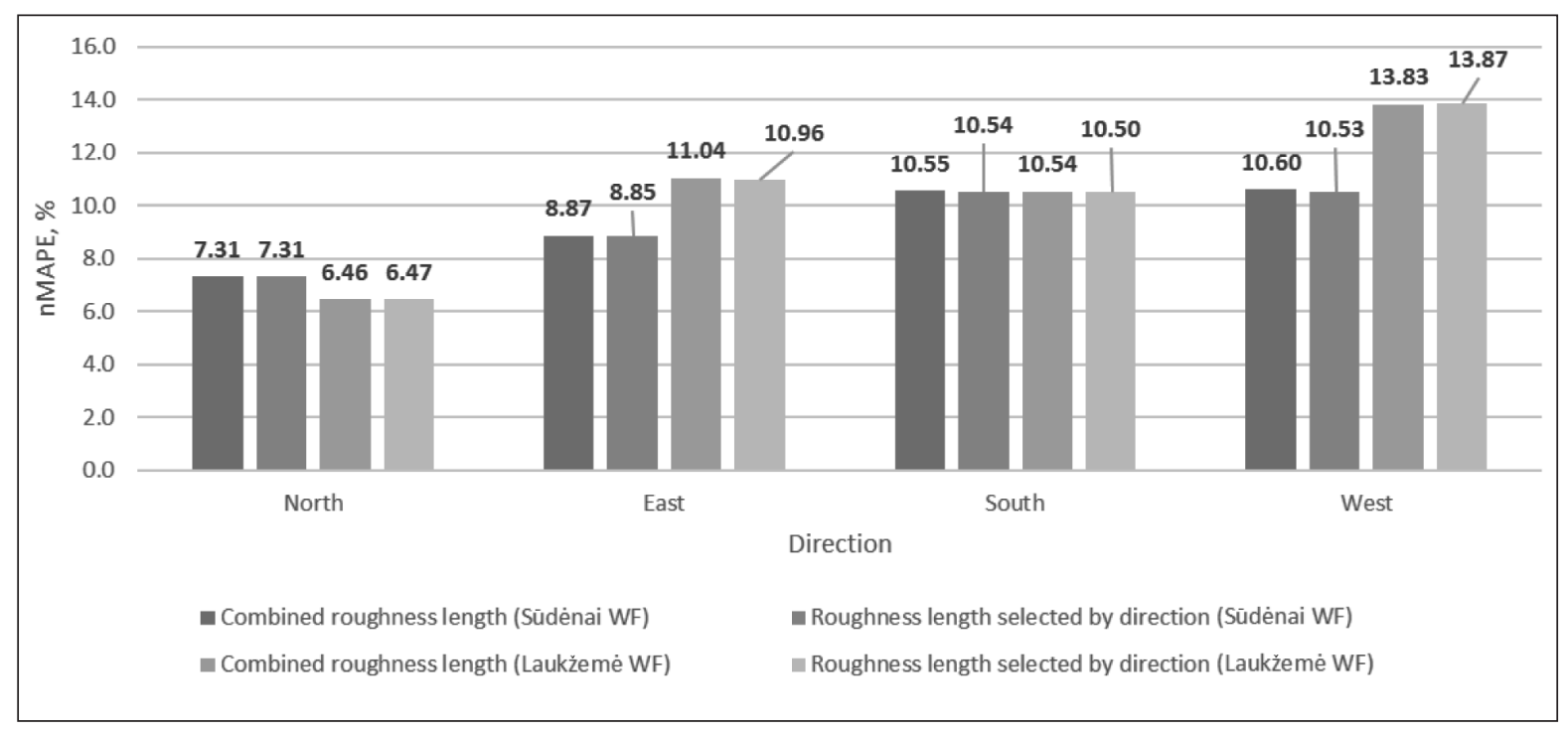

Fig. 1. Comparison of wind power prediction errors using combined and selected by direction roughness coefficients [6] 


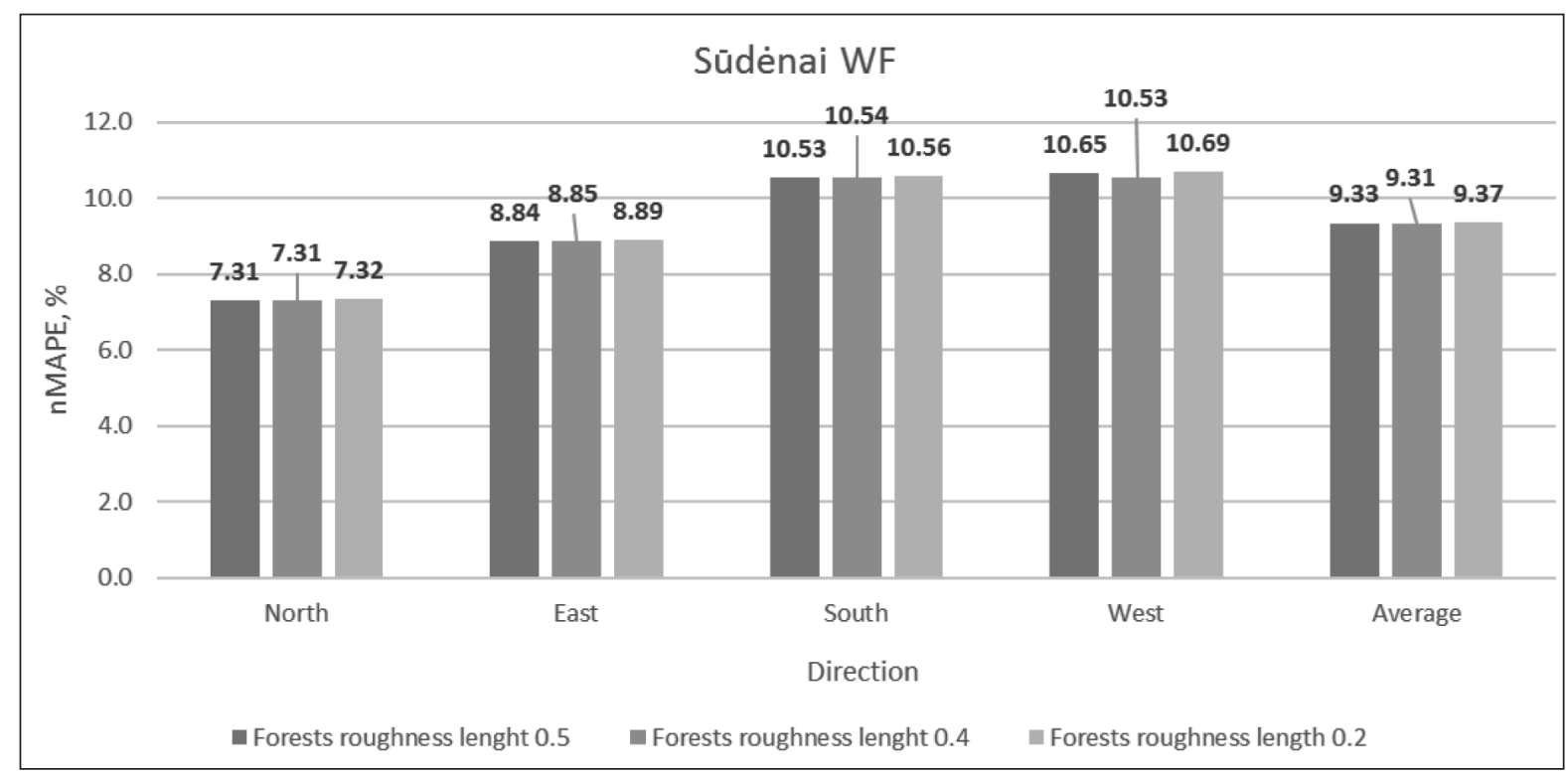

Fig. 2. Comparison of wind power prediction errors modelling surface roughness based on different trees coefficients in Sūdènai wind farm

coefficient 0.4 . A comparison of the average wind power prediction errors presents that the best suitable forest roughness coefficient is 0.4. However, differences are not significant. The same investigation in the Laukžemè wind farm was carried out and is presented in Fig. 3.

More accurate results were identified in North, East and South directions with coefficient 0.2. Average power prediction errors (nMAPE) of all directions were $10.44 \%$ and $10.45 \%$ with roughness coefficients 0.2 and 0.4 , respectively.

Investigation of the influence of terrain variations on wind changes and wind power prediction accuracy was made by WAsP 9 software, where wind speed changes due to relief variation (height lines) were estimated. The results of the influence of relief variations and summarised influence of topographical conditions are presented in Table 2.

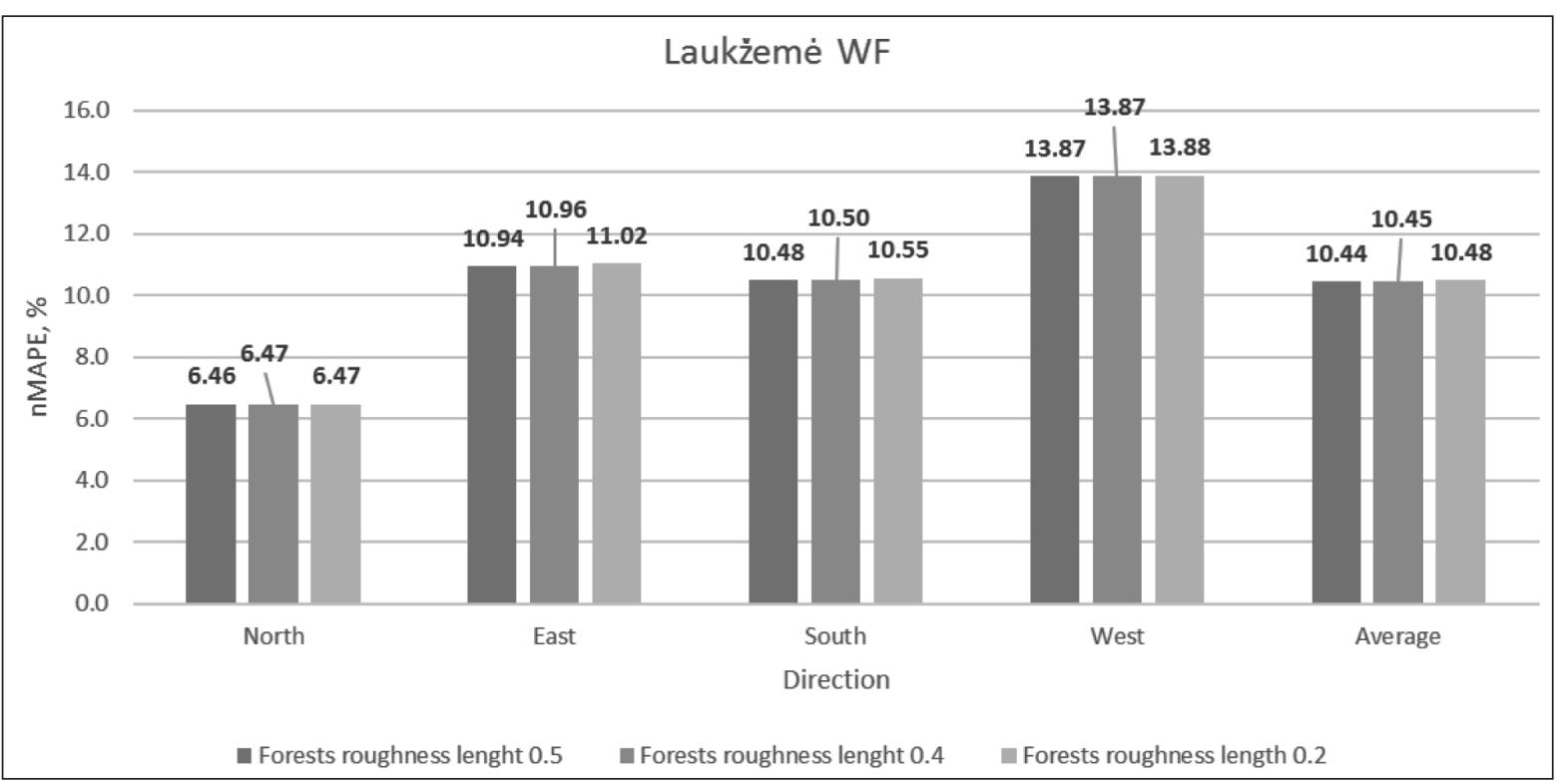

Fig. 3. Comparison of wind power prediction errors modelling surface roughness based on different tree roughness coefficients in Laukžemė wind farm 
Table 2. Wind power prediction errors including and not including the influence of topography

\begin{tabular}{|c|c|c|c|c|c|}
\hline \multirow[b]{2}{*}{ Title of wind farm } & \multicolumn{4}{|c|}{ Wind power prediction error, $\%$} & \multirow{2}{*}{$\begin{array}{c}\text { Total error } \\
\text { reduction, } \\
\%\end{array}$} \\
\hline & $\begin{array}{l}\text { Direct wind speed } \\
\text { conversion (wind } \\
\text { speed from NWP) }\end{array}$ & $\begin{array}{l}\text { Corrected wind } \\
\text { speed by surface } \\
\text { roughness length }\end{array}$ & $\begin{array}{l}\text { Corrected wind speed by } \\
\text { percentage wind speed changes } \\
\text { due to surface roughness length }\end{array}$ & $\begin{array}{l}\text { Corrected wind } \\
\text { speed by ter- } \\
\text { rain changes }\end{array}$ & \\
\hline Laukžemè WF & 12.25 & 10.45 & 10.26 & 10.2 & 2.05 \\
\hline Sūdènai WF & 11.01 & 9.31 & 9.28 & 9.16 & 1.85 \\
\hline
\end{tabular}

To conclude the section, it is very important to comment on the table above. It can be seen that direct wind speed (numerical weather prediction data) conversion to power generated $11.01-12.25 \%$ [3] prediction errors. To compare, estimation of surface roughness length decreased wind power prediction error by $1.7-1.8 \%$, and evaluation of terrain variations and percentage of wind speed changes due to surface roughness length decreased wind power prediction errors by $0.06-0.12 \%$ and $0.03-0.19 \%$, respectively. In total, a detailed roughness and terrain modelling, decreased forecasting errors up to $2.05 \%$.

Assessment of wind power prediction based on statistical methods

The wind power forecasting process based on statistical methods is very sensitive regarding wind power volatility and wind periods. Power prediction errors based on SARIMA method, considering estimated autoregressive and moving average parameters during different wind conditions are presented in Table 3.

It was noticed that during all kinds of wind periods, the increment of wind power prediction errors was directly related to time horizon, when during the period of 3-48 $\mathrm{h}$ ahead the nMAPE increased. The evaluation of short-term time horizon (up to 6 hours ahead) showed that the lowest errors were recognised during the low wind speed period with $3.68 \%$, and the highest during the high wind speed period with $14.70 \%[6]$.

In order to improve power prediction accuracy, statistical coefficients were estimated and integrated for the forecasting process. The coefficients were chosen every $5 \%$ of predictable power increment and decrease during different periods. The most suitable calculated coefficients were estimated and are presented in Table 4.

Table 3. Wind power prediction error distribution during different wind conditions periods ( $\mathrm{L}-\mathrm{low}$ wind speed period, $\mathrm{H}-\mathrm{high}$ wind speed period) [6]

\begin{tabular}{c|c|c|c|c}
\hline \multirow{2}{*}{ Wind power prediction period, $\mathbf{h}$} & \multicolumn{4}{|c}{ Wind speed period (Low - L, High - H) } \\
\cline { 2 - 5 } & L-L & L-H & H-L & H-H \\
\hline Average of nMAPE & 4.53 & 20.12 & 14.95 & 22.75 \\
\hline
\end{tabular}

Table 4. Wind power forecasting including and not including correction coefficients

\begin{tabular}{|c|c|c|c|c|c|}
\hline $\begin{array}{c}\text { Period } \\
\text { (24 hours) }\end{array}$ & $\begin{array}{l}\text { No power } \\
\text { correction }\end{array}$ & $\begin{array}{c}\text { Correction coef. when } \\
P<10,000 \mathrm{~kW}-0.85 \\
\text { and when } P>10,000 \\
\mathrm{~kW}-1.05\end{array}$ & $\begin{array}{c}\text { Correction coef. when } \\
P<10,000 \mathrm{~kW}-0.75 \\
\text { and when } P>10,000 \\
\mathrm{~kW}-1.15\end{array}$ & $\begin{array}{c}\text { Correction coef. when } \\
P<10,000 \mathrm{~kW}-0.65 \\
\text { and when } P>10,000 \\
\mathrm{~kW}-1.35\end{array}$ & $\begin{array}{l}\text { Total decreased } \\
\text { prediction error }\end{array}$ \\
\hline 1 & 7.04 & 6.30 & 8.12 & 8.73 & 0.74 \\
\hline 2 & 8.72 & 8.65 & 9.33 & 9.96 & 0.07 \\
\hline 3 & 3.52 & 3.54 & 5.46 & 5.50 & -0.01 \\
\hline 4 & 2.26 & 2.33 & 4.42 & 4.71 & -0.06 \\
\hline 5 & 7.96 & 7.84 & 9.87 & 9.64 & 0.12 \\
\hline Average & 5.90 & 5.73 & 7.44 & 7.71 & 0.17 \\
\hline
\end{tabular}


Investigation of acceptance of different coefficients indicates that upon inclusion of correction coefficients 0.75 when $P<10,000 \mathrm{~kW}$ and 1.15 when $P>10,000 \mathrm{~kW}$, as well as 0.65 when $P<10,000 \mathrm{~kW}$ and 1.35 when $P>10,000 \mathrm{~kW}$, power prediction errors were $7.44 \%$ and $7.71 \%$, respectively. Meanwhile, the prediction error without inclusion of coefficients was 5.9\%, and it means that the above-mentioned coefficients did not improve accuracy. However, inclusion of correction coefficients 0.85 when $P<10,000 \mathrm{~kW}$ and 1.05 when $P>10,000 \mathrm{~kW}$ resulted in the lowest prediction error (5.73\%). According to these results it can be claimed that the forecasting power could be corrected taking into consideration the correction coefficients 0.85 when $P<10,000 \mathrm{~kW}$ and 1.05 when $P>10,000 \mathrm{~kW}$.

Another statistical method for power prediction improvement is called the model output statistics. The method is based on linear relation between predicted and factual power during the period. An example of a 36-day period to determine the relation is presented in Fig. 4.

However, in order to maximise the forecasting accuracy, it is necessary to determine what is the best suitable duration for identification of statistical method parameters. The results of this investigation revealed that the best suitable duration is 6-12 days, compared to $24-36$ days. Besides, method adoption time was estimated for periods of 1-3 days and more than 36 days, but the determination coefficient was less than $40 \%$. It means that the relation between predicted and factual power was weak. To compare, in the period of 6-36 days the determination coefficient was in the limits of $0.65-0.75$.

As a result of inclusion and not inclusion of the MOS method (6-day adoption period) in Laukžemè and Sūdènai wind farms, power prediction errors were, respectively, $10.15 \%$ and 9.24\% without inclusion of MOS and $9.30 \%$ and $9.22 \%$ with MOS included.

\section{Summary of factors determining wind power prediction accuracy}

A detailed investigation of topographical conditions (Table 2) and wind characteristics was made and statistical models for power curve approximation and wind power forecasting were identified in earlier works [6]. The results of power prediction accuracy improvements are presented in Table 5, which indicate up to $3.45 \%$ reduction of wind power prediction errors compared to direct wind speed conversion to power.

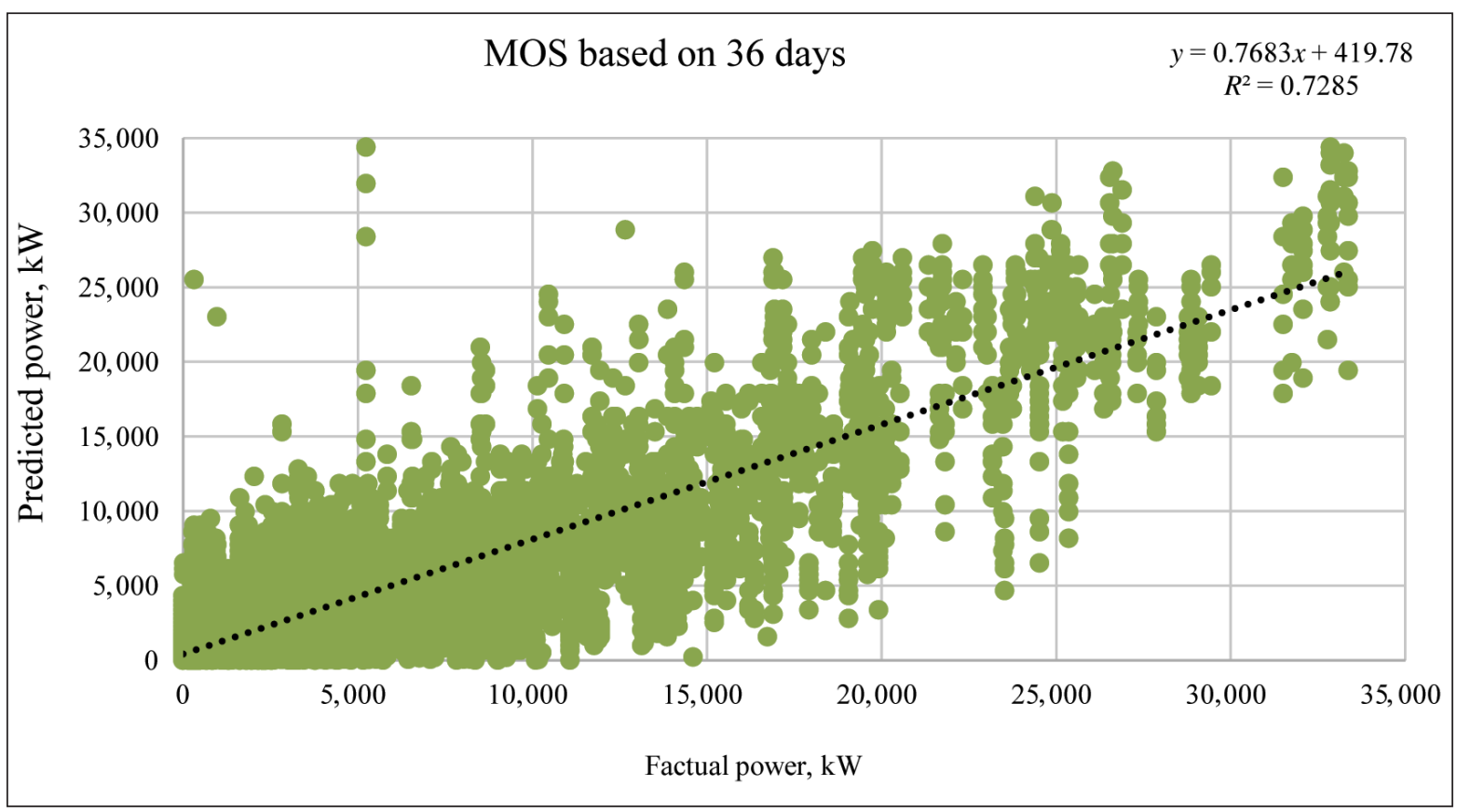

Fig. 4. Relation between predicted and factual power for 36-day period 
Table 5. Summary of methods when power prediction errors were decreased

\begin{tabular}{cc}
\hline Methods used for the reduction of power prediction errors & Decreased power prediction error, percentage points \\
\hline Detailed evaluation of topographical conditions & 1.95 \\
\hline Integration of SARIMA function & 0.86 \\
\hline Wind power correction methods & 0.17 \\
\hline Wind power correction based on MOS function & 0.47 \\
\hline Total decreased & 3.45 \\
\hline
\end{tabular}

It was evaluated that the main method for power prediction errors in Sūdenai and Laukžemè wind farms was evaluation of topographical conditions, where power prediction error could be decreased by up to $1.95 \%$. In terms of statistical methods, SARIMA method can improve power prediction accuracy by up to $0.86 \%$, and statistical predictable power correction methods by up to $0.64 \%$.

\section{CONCLUSIONS}

Analysis of the influence of topographic conditions on wind power prediction process accuracy has revealed that the use of different by wind direction surface roughness length indicators, included to power prediction process leads to the decrease of power forecasting errors. Moreover, the typical forests roughness length indicator (0.4) is the most suitable for surface modelling and determining the best wind power prediction accuracy. Estimation of wind speed changes depending on terrain variations lead to power prediction accuracy increase by $0.06-$ $0.12 \%$. A detailed assessment of topographic conditions can increase wind power prediction accuracy up to $2 \%$. The investigation of time series models has revealed that the best statistical function for power prediction is SARIMA, which is acceptable for 3-hour forecasting with $8.3 \%$ error. The model output statistics method increases power prediction accuracy by up to $0.5 \%$. The developed hybrid method predicts wind turbine power more accurately (by up to $3.5 \%)$ compared to direct wind speed conversion to power from NWP data.

Received 28 June 2018 Accepted 18 February 2019

\section{References}

1. REN21, Renewables 2017: Global Status Report. 2017. $301 \mathrm{p}$.

2. National Energy Independence Strategy, 2018. Ministry of Energy, Republic of Lithuania.

3. Zhang Y., Wang J., Wang X. Review on probabilistic forecasting of wind power generation. Renewable and Sustainable Energy Reviews. 2014. Vol. 32. P. 255-270.

4. Wang X., Guo P., Huang X. A review of wind power forecasting models. Energy Procedia. 2011. Vol. 12. P. 770-778.

5. Tascikaraoglu A., Uzunoglu M. A review of combined approaches for prediction of short-term wind speed and power. Renewable and Sustainable Energy Reviews. 2014. Vol. 34. P. 243-254.

6. Gecevičius G., Marčiukaitis M., Zimnickas V. Novel application of statistical and physical methods for wind power prediction in Lithuania. The 14th International Conference of Young Scientists on Energy Issues (CYSENI 2017), Kaunas, Lithuania, May 25-26, 2017. Kaunas: LEI, 2017. P. 86-93.

7. Gecevičius G., Marčiukaitis M., Zimnickas V. Analysis of wind power prediction errors using data of high resolution local area model. 13th Annual International Conference of Young Scientists on Energy Issues (CYSENI 2016), Kaunas, Lithuania, May 26-27, 2016. Kaunas: LEI, 2016. P. 82-88.

8. Troen I., Lundtang Petersen E. European Wind Atlas. 1989. ISSN 0014-2999.

9. Katinas V., Sankauskas D., Markevičius A., Perednis $E$. Investigation of the wind energy characteristics and power generation in Lithuania. Renewable Energy. 2014. Vol. 66. P. 299-304. 
10. Liu H., Shi J., Qu X. Empirical investigation on using wind speed volatility to estimate the operation probability and power output of wind turbines. Energy Conversion and Management. 2013. Vol. 67. P. 8-17.

11. Wang J., Hu J., Kailiang M., Zhanga Y. A self-adaptive hybrid approach for wind speed forecasting. Renewable Energy. 2015. Vol. 78. P. 374-385.

12. Lazić L., Pejanović G., Živković M., Ilić L. Improved wind forecasts for wind power generation using the Eta model and MOS (Model Output Statistics) method. Energy. 2014. Vol. 73. P. 567-574.

13. Lydia M., Kumar S. S., Selvakumar A. I., Prem Kumar G. E. A comprehensive review on wind turbine power curve modeling techniques. $R e$ newable and Sustainable Energy Reviews. 2014. Vol. 30. P. 452-460.

Giedrius Gecevičius, Mantas Marčiukaitis, Marijona Tamašauskienè

\section{VĖJO ELEKTRINIŲ GALIOS PROGNOZĖS TIKSLUMĄ LEMIANČIŲ VEIKSNIŲ TYRIMAS: VAKARŲ LIETUVOS ATVEJIS}

\section{Santrauka}

Siekiant mažinti klimato kaitą pastaraisiais metais vis daugiau dèmesio skiriama atsinaujinančiai, ypač vejjo, energetikai. Nepaisant visų vejo elektrinių privalu- mų ir minimalios itakos aplinkai, yra ir minusų. Vejo greičio pokytis yra stochastinis procesas, todèl sudètinga tiksliai prognozuoti vejjo elektrinių generuojamą galią. Netiksliai prognozuojama vejjo elektrinių galia gali sukeli elektros energetinès sistemos trikdžius, be to, reikalingi dideli ir ekonomiškai nenaudingi galios rezervai. Vèjo elektrinių generuojama galia gali būti prognozuojama statistiniu, fizikiniu ar hibridiniu metodais ir modeliais. Vis dèlto prognozuojant galią skirtingais metodais ir modeliais susidaro paklaidos įvairiais laiko periodais. Straipsnyje pateikiama vejo elektrinių generuojamos galios paklaidų analizè, generuojamą galią prognozuojant statistiniais, fizikiniais ir hibridiniais metodais. Tyrimas atskleidè, kad skirtingų statistinių metodų - netiesinès regresijos, MOS (angl. Model Output Statistics), tinkamiausios galios kreivès nustatymo funkcijų ir vejjo greičio korekcijos - taikymas leidžia galios prognozavimo paklaidas sumažinti iki 1,5\%. Išsamus reljefo pokyčio ir paviršiaus šiurkštumo vertinimas vejjo elektrinių galios prognozès tikslumą leidžia padidinti iki $2 \%$. Atsižvelgiant ị Vakarų Lietuvos sąlygas buvo nustatyta, kad trumpalaikei vejo elektrinių galios prognozei tinkamiausias yra hibridinis modelis, kuriuo detaliai ịvertinamos topografinès sąlygos, nes jame integruoti tiksliausi statistiniai metodai.

Raktažodžiai: vejjo elektrinių generuojamos galios prognozé, hibridinis modelis, fizikiniai metodai, statistiniai metodai 